\title{
Cellular Physiology

\section{Depot- and Gender-related Differences in the Lipolytic Pathway of Adipose Tissue from Severely Obese Patients}

\author{
Joana M. Ramis ${ }^{1}$, Ramón Salinas ${ }^{2}$, José M. García-Sanz ${ }^{2}$, José \\ Moreiro $^{3}$, Ana M. Proenza ${ }^{1}$ and Isabel Lladó ${ }^{1}$
}

\begin{abstract}
'Departament de Biologia Fonamental i Ciències de la Salut, Institut Universitari d'Investigació en Ciències de la Salut (IUNICS), Universitat de les Illes Balears, ${ }^{2}$ Servei de Cirurgia General i Digestiva, Hospital Universitari Son Dureta, ${ }^{3}$ Servei d’Endocrinologia i Nutrició, Hospital Universitari Son Dureta, Palma de Mallorca
\end{abstract}

\section{Key Words}

Adipocyte • Lipolytic pathway • Adrenergic receptors

- Severe obesity • Gender • Fat depot

\begin{abstract}
The present study was performed to analyze in detail gender- and site-related alterations in the adrenergic signal transduction pathway of lipolysis in fat cells isolated from subcutaneous abdominal and visceral fat depots from severely obese patients. The study group consisted of 30 morbidly obese subjects ( 9 men and 21 women) aged $41.1 \pm 1.9$ years, with a body mass index (BMI) of $54.7 \pm 1.7 \mathrm{~kg} / \mathrm{m} 2$, who had undergone abdominal surgery. Protein levels of hormone-sensitive lipase (HSL) and adrenergic receptors (AR), as well as HSL activity and the lipolytic response to adrenergic agents were analyzed. Both fat depots had similar basal lipolysis, but the capacity of catecholamines to activate lipolysis was greater in visceral fat, both at AR and postreceptor levels. Basal lipolysis and lipolytic activity induced by dibutyryl cyclic AMP were higher in men than in women. However, the visceral depot of women showed a higher maximal stimulation by noradrenaline than that of men, in accordance with higher $\beta_{1}$ - and $\beta_{3}$-AR protein levels.
\end{abstract}

\section{KARGER}

Fax +41613061234

E-Mail karger@karger.ch

www.karger.com
(C) 2006 S. Karger AG, Basel

1015-8987/06/0174-0173\$23.50/0

Accessible online at:

www.karger.com/journals/net
In conclusion, the main gender-related differences were located in the visceral depot, with women exhibiting a higher sensitivity to catecholamines associated with an increased provision of $\beta-A R$, while men showed an enhanced lipolytic capacity at the postreceptor level.

Copyright @ 2006 S. Karger AG, Basel

\section{Introduction}

Lipolysis in fat cells is mainly regulated by the adrenergic system. Catecholamine effects are modulated through four different G-protein-coupled adrenergic receptor (AR) subtypes. $\beta$-ARs $\left(\beta_{1}, \beta_{2}\right.$ and $\beta_{3}$ ) stimulate lipolysis by increasing the formation of cyclic AMP (cAMP), which leads to the stimulation of protein kinase A (PKA) and the phosphorylation of both the accessory protein perilipin and hormone-sensitive lipase (HSL). In contrast, the $\alpha_{2}$-AR subtype inhibits lipolysis by decreasing cAMP formation. Thus, the net effect of catecholamines on adipose tissue is dependent on the functional balance between $\beta$ - and $\alpha_{2}$-AR mediated signal transduction [1$3]$. Although HSL is considered the rate-limiting enzyme 
catalysing lipolysis, the presence of an additional triglyceride lipase in adipose tissue has been recently identified [4-6]; this could also play a role in the lipolytic process, acting in coordination with HSL.

Energy homeostasis can be affected by alterations in the lipolytic pathway contributing to both the development and pathogenesis of obesity [7]. Several differences in the rate of lipolysis have been observed between various fat depots from humans [8-12], with higher lipolytic activity in the visceral adipose tissue than in the subcutaneous one. Numerous studies have emphasized the idea that visceral fat deposition is strongly correlated to the metabolic complications of obesity, such as hypertension, cardiovascular disease, and noninsulindependent diabetes mellitus [13, 14].

Moreover, variations in lipolytic activity have also been shown to be gender dependent [15]. Thus, differences between men and women have been observed in the sensitivity to adrenergic stimulation [16, 17], as well as in the rate of lipolysis induced by agents acting at different steps of the lipolytic pathway [16-19].

Previous studies have focused on changes at certain steps of the lipolytic pathway in either only one fat depot or in several, making comparisons between adipose tissues from different anatomical locations. However, in some studies data on men and women have either been analyzed together or genders have been studied in separate works. Thus, the aim of this study was to analyze in detail the different steps of the adrenergic pathway, in order to evaluate the overall effect of both gender and fat depot on the adipocyte lipolytic capacity. For this purpose, we analyzed protein levels of HSL and of the adrenergic receptors, as well as HSL activity and the lipolytic response to different adrenergic agents acting at different steps of the lipolytic pathway in adipocytes isolated from subcutaneous abdominal and visceral adipose tissues from morbidly obese men and women.

\section{Materials and Methods}

\section{Materials}

Antibodies for $\beta$-ARs and $\alpha_{2 \mathrm{~A}}$-AR were from Santa Cruz Biotechnology (Santa Cruz, CA). Antibodies for HSL were kindly supplied by FB Kraemer [20]. ( \pm )-Noradrenaline bitartrate salt, (-)-isoproterenol (+)-bitartrate salt (isoprenaline), dobutamine hydrochloride, terbutaline hemisulfate salt, forskolin, dibutyryl cAMP ( $\left.\mathrm{Bt}_{2} \mathrm{cAMP}\right)$, bovine serum albumin (fraction V), Clostridium histolyticum collagenase type II and triglyceride GPO-Trinder $\left(\mathrm{n}^{\circ}\right.$ 337) were obtained from Sigma (St Louis, Mo). RS79948 hydrochloride was obtained from TOCRIS

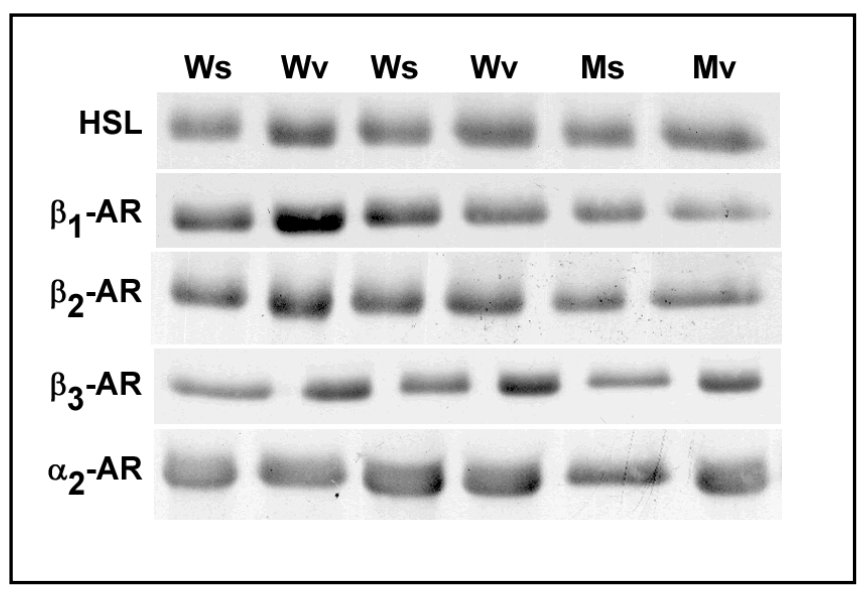

Fig. 1. Western blot analysis of HSL, $\beta_{1}^{-}, \beta_{2}-, \beta_{-}^{-}$, and $\alpha_{2}{ }^{-A R}$ protein levels in subcutaneous (s) and visceral (v) adipose tissue depots of severely obese men (M) and women (W).

(Madrid, Spain). Glycerol tri $\left[9,10(\mathrm{n})-{ }^{3} \mathrm{H}\right]$ oleate and $\left[{ }^{14} \mathrm{C}\right]$ oleic acid were supplied by American Radiolabeled Chemicals (St Louis, Mo). Aprotinin and leupeptin were supplied by Roche Diagnostics (Basel, Switzerland). Routine chemicals were provided by Amersham Pharmacia Biotech (Piscataway, NJ), Panreac (Barcelona, Spain), and Sigma.

\section{Subjects and adipose tissue biopsies}

The study group consisted of 30 morbidly obese -nondiabetic- subjects ( 9 men and 21 women) aged $41.1 \pm 1.9$ years (23-60 years), with a body mass index (BMI) of $54.7 \pm 1.7 \mathrm{~kg} / \mathrm{m}^{2}$ $\left(40-81 \mathrm{~kg} / \mathrm{m}^{2}\right)$, who were undergoing weight reduction surgery by biliopancreatic diversion [21]. None of them used any regular medication. The study protocol was approved by the Ethics Committee of the Son Dureta University Hospital (Palma de Mallorca, Spain) and all subjects gave their written consent to participate in the study. Fasting plasma glucose, insulin, triglycerides and cholesterol were measured by the hospital's routine laboratory. Fat biopsies were removed in each subject from both abdominal subcutaneous and visceral (omental) adipose tissues and were obtained within $20 \mathrm{~min}$ after the start of general anaesthesia. Tissue biopsies were immediately frozen in liquid nitrogen and stored at $-80^{\circ} \mathrm{C}$ for subsequent analysis. Fresh adipose tissue samples were taken in Krebs-Ringer bicarbonate (KRB) buffer (pH 7.4), containing 10 mM HEPES and $6 \mathrm{mM}$ glucose for adipocyte isolation and subsequent lipolysis assay.

\section{Adipocyte isolation and lipolysis assay}

Adipocytes were isolated using the method described by Robdell [22] with some minor modifications. Briefly, tissue samples were minced at room temperature and incubated for 35 min with $1.5 \mathrm{~g} / \mathrm{L}$ of collagenase in $10 \mathrm{~mL}$ buffer (pregassed with $95 \% \mathrm{O}_{2}-5 \% \mathrm{CO}_{2}, \mathrm{pH} 7.4$ ), containing $10 \mathrm{mM}$ HEPES, $6 \mathrm{mM}$ glucose and $30 \mathrm{~g} / \mathrm{L}$ of bovine serum albumin at $37^{\circ} \mathrm{C}$ in a shaking bath. Cells were filtered through a nylon mesh $(250 \mathrm{ì} \mathrm{m})$ and subsequently washed three times with a collagenase-free buffer. 
Table 1. Biometric and serum biochemical parameters of severely obese subjects. Results are the mean \pm S.E.M of 9 men and 21 women. Data were analyzed by Student's t test. NS non significant.

\begin{tabular}{llll}
\hline & \multicolumn{1}{c}{ Men } & Women & $\mathrm{p}$ \\
\hline Age $(\mathrm{y})$ & $41.9 \pm 3.4$ & $40.7 \pm 2.3$ & $\mathrm{NS}$ \\
Body mass index $\left(\mathrm{kg} / \mathrm{m}^{2}\right)$ & $57.8 \pm 2.3$ & $53.4 \pm 2.2$ & $\mathrm{NS}$ \\
Glucose $(\mathrm{mmol} / \mathrm{L})$ & $6.11 \pm 0.48$ & $5.75 \pm 0.21$ & $\mathrm{NS}$ \\
Insulin $(\mu \mathrm{U} / \mathrm{mL})$ & $28.9 \pm 4.4$ & $23.2 \pm 2.8$ & $\mathrm{NS}$ \\
Triglycerides $(\mathrm{mmol} / \mathrm{L})$ & $1.59 \pm 0.12$ & $1.54 \pm 0.16$ & $\mathrm{NS}$ \\
Cholesterol $(\mathrm{mmol} / \mathrm{L})$ & $3.64 \pm 0.27$ & $3.81 \pm 0.36$ & $\mathrm{NS}$ \\
\hline
\end{tabular}

Cell counts were performed with an improved Neubauer hemocytometer. The mean adipocyte diameter was calculated by direct microscopy from the measurement of 50 cells in each tissue sample. Assuming that fat cells are spheres, the mean fat cell volume was calculated from these values.

Measurements of lipolytic activity were performed by incubating isolated adipocytes $(25,000$ cells $/ \mathrm{mL})$ at $37^{\circ} \mathrm{C}$ in a shaking bath in $0.5 \mathrm{~mL}$ of KRB buffer containing $10 \mathrm{mM}$ HEPES, $6 \mathrm{mM}$ glucose, and $30 \mathrm{~g} / \mathrm{L}$ of bovine serum albumin in the presence of increasing concentrations of lipolytic agents under an atmosphere of $5 \% \mathrm{CO}_{2}$ in $\mathrm{O}_{2}$. The ligands and concentrations used in this study were: noradrenaline $\left(\beta_{1}-, \beta_{2}^{-}, \beta_{3}\right.$ - and $\alpha_{2}-\mathrm{AR}$ agonist) from $10^{-9}$ to $10^{-5} \mathrm{M}$ and isoprenaline $\left(\beta_{1-}^{-}, \beta_{2^{-}}\right.$, and $\beta_{3^{-}}$ AR agonist) from $10^{-10}$ to $10^{-6} \mathrm{M}$, dobutamine ( $\beta_{1}$-AR agonist) from $10^{-10}$ to $10^{-4} \mathrm{M}$, terbutaline $\left(\beta_{2}-\mathrm{AR}\right.$ agonist) from $10^{-10}$ to $10^{-3} \mathrm{M}$, forskolin (stimulating adenylate cyclase) $10^{-5} \mathrm{M}$, and $\mathrm{Bt}_{2} \mathrm{cAMP}$ (cAMP analogous resistant to phosphodiesterase and stimulating PKA) $10^{-3} \mathrm{M}$. The maximal effective concentrations of forskolin and $\mathrm{Bt}_{2} \mathrm{cAMP}$ were assessed by preliminary dose-effect analysis. Moreover, lipolytic responses to increasing doses (from $10^{-9} \mathrm{M}$ to $10^{-5} \mathrm{M}$ ) of noradrenaline were measured with $10 \mu \mathrm{M}$ of the $\alpha_{2}$-AR antagonist RS79948.

After 90 min of incubation, the reaction was stopped in a water ice bath and aliquots $(200 \mu \mathrm{L})$ of the cell-free medium were taken to determine the glycerol concentration, as an index of lipolysis. The glycerol content of the deproteinated aliquots was determined enzymatically with a chemical kit.

\section{HSL activity measurement}

Adipose tissue samples were homogenized in a buffer containing $0.25 \mathrm{M}$ sucrose, $10 \mathrm{mM}$ HEPES, $1 \mathrm{mM}$ EDTA, $1 \mathrm{mM}$ dithiothreitol, and $0.005 \%$ heparin $(\mathrm{pH} 7.5)$ and then centrifuged (400xg for $10 \mathrm{~min}$ at $4^{\circ} \mathrm{C}$ ). The fat-free infranatant was used to determine HSL activity as previously described [23].

The infranatant was also used to determine the protein content [24] to standardize HSL activity.

HSL, $\beta_{1}-, \beta_{2}-, \beta_{3}$ and $\alpha_{2}-A R$ protein level determination

A small piece of frozen tissue $(\sim 500 \mathrm{mg})$ was homogenized in phosphate-buffered saline buffer $(137 \mathrm{mM} \mathrm{NaCl}, 3 \mathrm{mM} \mathrm{KCl}$, $6.5 \mathrm{mM} \mathrm{Na}_{2} \mathrm{HPO}_{4}$, and $3.5 \mathrm{mM} \mathrm{KH}_{2} \mathrm{PO}_{4}$ ) with freshly added protease inhibitors ( $1 \mu \mathrm{g} / \mathrm{mL}$ aprotinin, $1 \mu \mathrm{g} / \mathrm{mL}$ leupeptin, and $10 \mu \mathrm{g} / \mathrm{mL}$ phenylmethyl sulfonyl fluoride). The homogenate was centrifuged at $16,000 \mathrm{xg}$ for $20 \mathrm{~min}$ at $4^{\circ} \mathrm{C}$, and the fat-free infranatant was removed and stored at $-20^{\circ} \mathrm{C}$. After protein

Lipolytic Capacity in Severely Obese Men and Women content determination [24], varying amounts of total protein from the homogenates ( $50 \mu \mathrm{g}$ for HSL, $\beta_{1}-, \beta_{2}-$, and $\alpha_{2}$-ARs, and $35 \mu \mathrm{g}$ for $\beta_{3}$-AR) were fractionated by sodium dodecyl sulfate polyacrylamide gel electrophoresis ( $10 \%$ polyacrylamide), and electrotransferred on a nitrocellulose filter as described elsewhere [25]. Development of the immunoblots was performed using an enhanced chemiluminescence Western blotting analysis system. Rabbit polyclonal antibodies against HSL, $\beta_{1}-, \beta_{2}^{-}$, and $\beta_{3}$-ARs, and goat polyclonal antibody against $\alpha_{2}$-AR were used as primary antibodies. Bands in films were analysed by scanner photodensitometry and quantified using the Kodak 1D Image Analysis Software 3.5 for windows. Representative western blots are shown in Figure 1.

\section{Statistical analysis}

The lipolytic activity was expressed as nmoles of glycerol per $10^{6}$ cells $/ 90 \mathrm{~min}$ and percentage stimulation over basal lipolysis levels (basal lipolysis was set to be $100 \%$ and was calculated for each individual). All AR agonists caused a concentration-dependent stimulation of glycerol release which reached a plateau at the highest agonist concentrations. Doseresponse curves for agonists were fitted with nonlinear regression analysis for sigmoid curves, as previously described [26], using the GraFit computer program (Leatherbarrow R. J. GraFit version 4, Erithacus Software, Staines, UK, 1998). This data processing allowed us to calculate the maximal stimulation of the glycerol release over basal lipolysis induced by each agonist. Likewise, the statistical differences between groups in the maximal capacity values were obtained using the same program and the procedure described by Motulsky and Ransnas [26] to compare parameters of curves fitted by nonlinear regression.

Protein mass (integrated optical density units per microgram of total tissue protein) data are expressed relative to the mean value of the male subcutaneous group, which was set as $100 \%$. Differences between genders in biometric and serum biochemical parameters were tested using Student's ttest. Adipocyte volume, protein levels of HSL, $\beta_{1}^{-}, \beta_{2}^{-}, \beta_{3}-$ and $\alpha_{2}$-ARs, HSL activity, basal lipolysis and maximal lipolysis induced by forskolin and $\mathrm{Bt}_{2} \mathrm{cAMP}$ were assessed by two-way analysis of variance (ANOVA) and also by Student's t test as post hoc comparison, but only when an interactive effect of depot and gender (DxG) was shown. Analyses were performed using SPSS 11.5 software for windows. A p-value of less than 0.05 was considered statistically significant. 
Fig. 2. Noradrenalinestimulated lipolysis in subcutaneous (sc) and visceral (vs) adipocytes isolated from morbidly obese subjects. Data are means \pm S.E.M. Glycerol release rates are expressed as nmol glycerol $/\left(10^{6}\right.$ cells x $\left.90 \mathrm{~min}\right)$ and are minus basal lipolysis values. Significant differences were assessed using ANOVA ( $p<0.05)$ : D effect of adipose tissue depot.

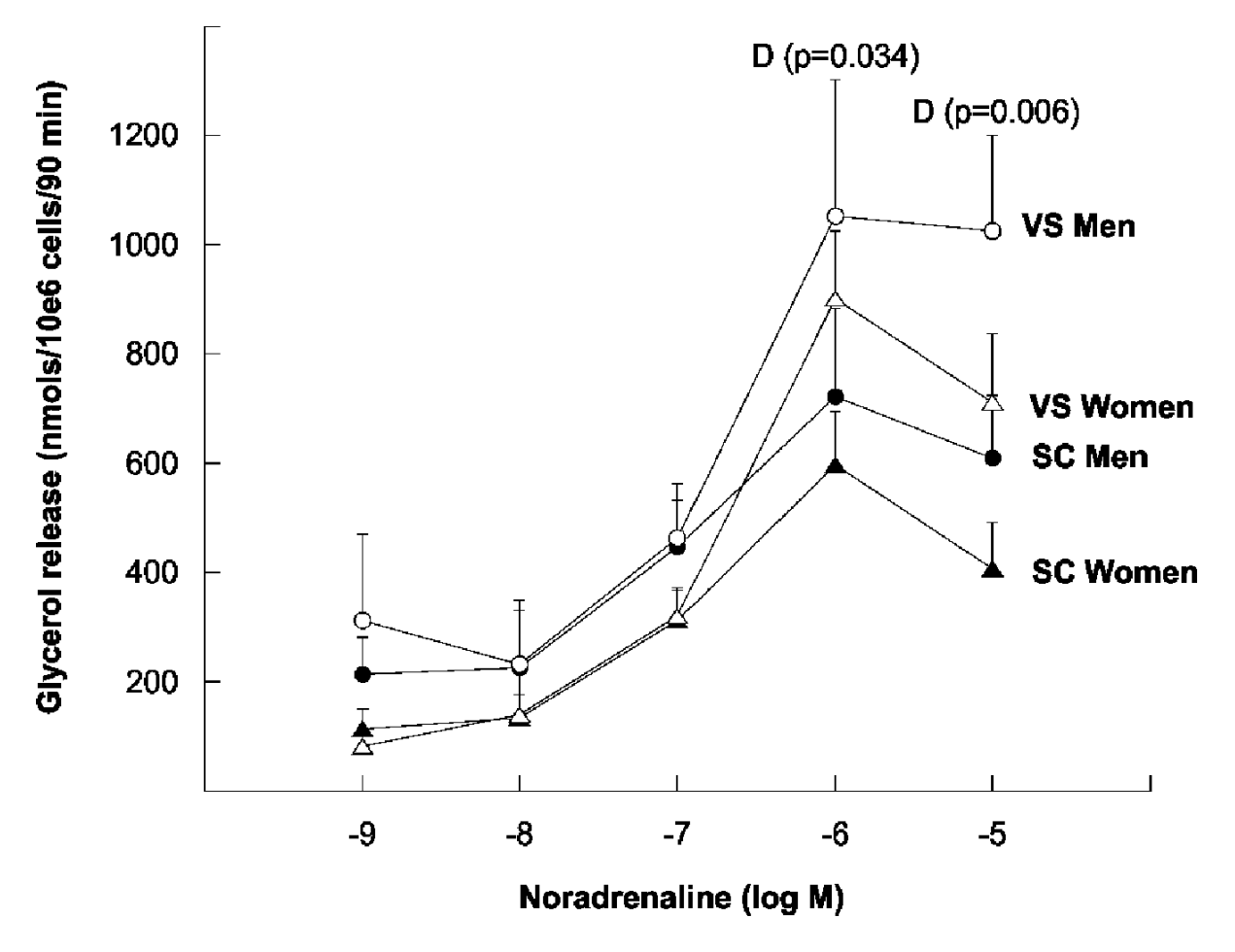

\section{Results}

The biometric and serum biochemical parameters of the subjects included in the study are shown in Table 1. No statistical differences were found between men and women in any of the parameters considered. Fasting glucose and insulin levels were similar to the ones described for severely obese patients [27, 28].

Different AR agents were used to stimulate lipolysis in isolated fat cells -noradrenaline $\left(\beta_{1}-, \beta_{2}^{-}, \beta_{3}\right.$ - and $\alpha_{2}$-AR agonist), isoprenaline ( $\beta_{1}-, \beta_{2}-$, and $\beta_{3}$-AR agonist), dobutamine ( $\beta_{1}$-AR agonist), terbutaline ( $\beta_{2}$-AR agonist), and RS79948 $\left(\alpha_{2}\right.$-AR antagonist). Figure 2 shows the mean concentration-response curves for noradrenaline in subcutaneous and visceral fat depots from obese men and women. Noradrenaline increased glycerol release in a concentration-dependent manner. The stimulation of lipolysis induced by noradrenaline was 1.5 -fold more effective in isolated fat cells from the visceral depot than subcutaneous one and tended to be higher in men than in women, without reaching statistical significance. Adipocyte volume, basal lipolysis and the maximum action of lipolytic agents, expressed as percentage of stimulation over basal lipolysis levels, are shown in Table 2. Adipocyte volume was higher in both adipose tissues from men than in those from women. Basal lipolysis was higher in men than in women. All agonists stimulated glycerol release in a concentration-dependent manner. In both genders, visceral adipose tissue showed higher lipolysis stimulation by noradrenaline and dobutamine than the subcutaneous one. Moreover, the visceral depot of women showed a higher maximal stimulation by noradrenaline than that of men. In subcutaneous fat from both genders, noradrenaline acted as a partial agonist with values for intrinsic activity of $<77 \%$ of isoprenaline action.

As an index of lipolytic potencies of fat cells, agents by-passing the receptor step such as forskolin and $\mathrm{Bt}_{2} \mathrm{cAMP}$ were tested. The lipolytic activity induced by forskolin and $\mathrm{Bt}_{2} \mathrm{cAMP}$ at their maximal effective concentrations as we assessed with preliminary experiments $\left(10^{-5} \mathrm{M}\right.$ and $10^{-3} \mathrm{M}$, respectively) is shown in Table 3. The glycerol released after forskolin stimulation did not show significant differences either depot- or gender-dependent. The maximal lipolytic activity induced by $\mathrm{Bt}_{2} \mathrm{cAMP}$ was greater in men than in women, being similar in both adipose depots.

The visceral depot showed higher $\beta$-AR levels than the subcutaneous one (Table 4), although values did not reach statistical significance. Gender differences were found in $\beta_{1}$ - and $\beta_{3}$-AR levels, since women showed a greater protein content than men.

Visceral fat showed higher HSL mass levels (Table 5) than the subcutaneous one, in both men and women. On the other hand, HSL activity values were greater in 
Table 2. Cell volume, basal lipolysis and adrenergic stimulated lipolytic activity of subcutaneous and visceral adipocytes isolated from severely obese subjects. Results are the mean \pm S.E.M. Basal lipolysis is expressed as nmol glycerol/ $\left(10^{6}\right.$ cells x 90 min). Maximal action of lipolytic agents is expressed as percentage stimulation over basal lipolysis levels (which were set to be $100 \%$ ), and was obtained by curve fitting analysis performed by nonlinear regression using the GraFit computer program and curves were compared using the

\begin{tabular}{lccccc}
\hline & \multicolumn{3}{c}{ Men } & \multicolumn{2}{c}{ Women } \\
& Subcutaneous & Visceral & Subcutaneous & Visceral & ANOVA (p) \\
\hline Fat cell volume (pl) & $897 \pm 147$ & $1006 \pm 89$ & $743 \pm 46$ & $698 \pm 70$ & $G(0.010)$ \\
Basal lipolysis & $1021 \pm 301$ & $815 \pm 116$ & $677 \pm 92$ & $559 \pm 43$ & $G(0.024)$ \\
Maximal stimulation & & & & & \\
Noradrenaline & $93.0 \pm 10.3$ & $153 \pm 18$ & $92.9 \pm 0.9$ & $196 \pm 3 * 0$ & \\
RS79948 & $128 \pm 35$ & $174 \pm 58$ & $139 \pm 9$ & $189 \pm 36$ & \\
Isoprenaline & $157 \pm 22$ & $192 \pm 20$ & $155 \pm 12$ & $196 \pm 11$ & \\
Dobutamine & $65.2 \pm 12.9$ & $148 \pm 72$ & $61.2 \pm 8.2$ & $114 \pm 12 *$ & \\
Terbutaline & $133 \pm 18$ & $163 \pm 23$ & $131 \pm 18$ & $173 \pm 14$ & \\
Noradrenaline & $76.3 \pm 9.4$ & $85.3 \pm 9.7$ & $71.1 \pm 6.0$ & $101 \pm 10$ & $D(0.010)$ \\
Intrinsic Activity & & & & & \\
\hline
\end{tabular}

procedure described by Motulsky and Ransnas [26]. Lipolytic responses to increasing doses of noradrenaline were measured with and without $10 \mu \mathrm{M}$ of the $\alpha_{2}$-AR antagonist RS79948. Significant differences in fat cell volume, basal lipolysis and noradrenaline intrinsic activity were assessed using ANOVA ( $p<0.05)$ : $\mathrm{G}$ effect of gender, D effect of adipose tissue depot. Significant differences in maximal lipolysis over basal lipolysis: * visceral vs subcutaneous, o women vs men.

Table 3. Lipolytic activity induced by forskolin and $\mathrm{Bt}_{2} \mathrm{cAMP}$ in subcutaneous and visceral adipocytes isolated from severely obese subjects. Results are the mean \pm S.E.M. Lipolytic activity was expressed at their maximal effective concentrations $\left(10^{-5}\right.$ and $10^{-3} \mathrm{M}$, respectively) as a percentage over

\begin{tabular}{lccccc}
\hline & \multicolumn{2}{c}{ Men } & \multicolumn{2}{c}{ Women } & \\
& Subcutaneous & Visceral & Subcutaneous & Visceral & ANOVA (p) \\
\hline Forskolin & $242 \pm 50$ & $216 \pm 39$ & $252 \pm 30$ & $306 \pm 36$ & NS \\
$\mathrm{Bt}_{2}$ cAMP & $331 \pm 60$ & $279 \pm 68$ & $201 \pm 19$ & $219 \pm 32$ & $G(0.032)$ \\
\hline
\end{tabular}
basal lipolysis (which was set to be $100 \%$ ). Data were analyzed by two-way analysis of variance (ANOVA). Significant differences $(\mathrm{p}<0.05)$ : $G$ effect of gender. $N S$ non significant.

the subcutaneous depot than in the visceral one.

\section{Discussion}

In this study, both depot- and gender-dependent effects on the lipolytic capacity of adipocytes from morbidly obese subjects were investigated. Our results point to a higher lipolytic activity in visceral than subcutaneous adipose tissue, due to a lower inhibition of lipolysis via $\alpha_{2}$-AR and increased lipolytic activity through $\beta_{1}$-AR. Moreover, in both tissues, men were able to counteract the lower lipolytic capacity at the level of adrenergic receptors - compared to women - by a higher lipolytic capacity at the postreceptor level. Thus, the

Lipolytic Capacity in Severely Obese Men and Women variations in lipolytic capacity between genders are determined at or beyond the level of PKA.

\section{Depot-dependent differences in lipolytic capacity in adipose tissue depots from severely obese patients}

Similarly to previous reports by other authors $[8,11$, $12,15]$ we found marked variations in lipolytic capacity between subcutaneous and visceral adipose tissues from obese subjects. In fact, it has been proposed that in obese subjects the regional variations in the action of catecholamines on lipolysis are enhanced, due to differences in the activity of the different ARs, insulin receptors and HSL function [10]. The higher lipolytic response to noradrenaline observed in the visceral 
Table 4. Adrenergic receptor protein levels in subcutaneous and visceral adipose tissues from severely obese subjects. Results are the mean \pm S.E.M. Protein arbitrary units (AU) mean values of subcutaneous depot from men were set as $100 \%$. Data were analyzed by twoway analysis of variance (ANOVA). Significant differences ( $\mathrm{p}<0.05)$ : $G$ effect of gender. NS non significant.

\begin{tabular}{cccccc}
\hline \multicolumn{5}{c}{ Men } & \multicolumn{2}{c}{ Women } & \\
& Subcutaneous & Visceral & Subcutaneous & Visceral & ANOVA (p) \\
\hline Protein level (AU) & $100 \pm 15$ & $112 \pm 18$ & $137 \pm 13$ & $163 \pm 13$ & $(i(0.009)$ \\
$\beta 1$ & $100 \pm 14$ & $114 \pm 10$ & $130 \pm 22$ & $163 \pm 20$ & $N S$ \\
$\beta 3$ & $100 \pm 10$ & $145 \pm 23$ & $199 \pm 32$ & $216 \pm 28$ & $(i(0.030)$ \\
$\alpha 2$ & $100 \pm 9$ & $99.8 \pm 10.3$ & $119 \pm 10$ & $127 \pm 9$ & $N S$ \\
\hline
\end{tabular}

Table 5. HSL protein levels and enzyme activity of subcutaneous and visceral adipose tissues from severely obese subjects. Results are the mean \pm S.E.M. Protein arbitrary units (AU) mean values of subcutaneous depot from men were set as $100 \%$. HSL activity was

\begin{tabular}{lccccc}
\hline & \multicolumn{2}{c}{ Men } & \multicolumn{2}{c}{ Women } \\
& Subcutaneous & Visceral & Subcutaneous & Visceral & ANOVA (p) \\
\hline $\begin{array}{c}\text { Protein levels (AU) } \\
\begin{array}{c}\text { Enzyme activity } \\
(\text { U/g protein) }\end{array}\end{array}$ & $100 \pm 16$ & $161 \pm 18$ & $151 \pm 18$ & $178 \pm 15$ & $D(0.037)$ \\
\hline
\end{tabular}
expressed as $\mu \mathrm{U} / \mathrm{g}$ of tissue protein, $1 \mu \mathrm{U}$ was equal to $1 \mu \mathrm{mol}$ nonesterified fatty acids released per hour of incubation at $37^{\circ} \mathrm{C}$. Data were analyzed by two-way analysis of variance (ANOVA). Significant differences ( $<<0.05)$ : $D$ effect of adipose tissue depot.

compared with the subcutaneous fat depot could be explained in part by a higher provision of $\beta$-ARs in the former, but also by a greater inhibitory effect via $\alpha_{2}$-AR in the latter. The results obtained when increasing doses of noradrenaline were tested in the presence of the $\alpha_{2}$-AR antagonist RS79948 are in agreement with intrinsic activity data and point to differences in $\alpha_{2}$-AR function, possibly contributing to the observed depot-dependent variations. Moreover, changes at the postreceptor step must also be considered, mainly at the level of the rate limiting enzyme catalyzing lipolysis, HSL, which showed higher protein levels in visceral than in subcutaneous adipose tissue. Thus, although both tissues had a similar basal lipolysis, visceral fat had a greater capacity to activate lipolysis in response to catecholamines, as a result of a signal transduction system which was more focused toward lipid mobilization, both at AR and postreceptor steps.

In agreement with previously reported data, HSL activity was higher in the subcutaneous adipose tissue compared to the visceral one [29]. In contrast, the HSL mass was higher in the visceral fat, which might be a sign of the regulation of the enzyme at the posttranslational level $[28,30]$ or of the presence of a truncated form of the enzyme with reduced activity which has been found in human adipose tissue [31]; regretfully, the conditions we used to detect HSL mass did not allow the differentiation between these two forms.

Gender differences in the lipolytic capacity of adipocytes from subcutaneous and visceral fat depots

In the present study, a gender dimorphism was found at the level of different elements of the adrenergic pathway leading to lipolysis. The markedly increased basal rate of lipolysis in both fat depots from men compared to women correlated with the men's larger fat cells, in accordance with previously reported results [28, 32, 33], and also with a higher lipoprotein lipase activity [34]. Moreover, the lipolytic capacity and the effect of noradrenaline on lipolysis in fat depots of obese subjects were also influenced by gender. The lower maximal stimulation over basal lipolysis induced by noradrenaline in the visceral fat of men could be due to a higher resistance to the action of catecholamines compared to women, in a similar way as has been reported in the subcutaneous fat from obese patients [28]. Thus, the inability of adipose tissue from men to increase the lipolytic capacity over basal lipolysis like women do together with their increased basal lipolysis might be related with the fact that men are more prone to accumulate fat in the abdominal region than women, and

Ramis/Salinas/García-Sanz/Moreiro/Proenza/Lladó 
could explain, at least in part, gender differences in the resistance to weight reduction.

In both adipose tissues, women showed a provision of ARs more focused toward lipid mobilization, with higher levels of $\beta_{1}$ - and $\beta_{3}$-AR expression and, in the visceral fat, an increased response to dobutamine. An enhanced lipolytic function of $\beta$-ARs, especially $\beta_{3}$-AR, has been proposed to be one of the mechanisms responsible for the increased catecholamine-induced lipolysis in the visceral fat with obesity $[12,35]$. In addition to the differences in the amount of different ARs, other elements of the lipolytic pathway at the postreceptor level must be taken into account to be differentially regulated in men and women. The study carried out by incubating adipocytes with forskolin (stimulating adenylate cyclase) and $\mathrm{Bt}_{2} \mathrm{cAMP}$ (which activates PKA) confirmed the existence of a gender dimorphism also at the postreceptor level. Thus, the lipolysis induced by $\mathrm{Bt}_{2} \mathrm{cAMP}$ was 1.7and 1.3-fold higher in subcutaneous and visceral depots from men, respectively, compared to women, which would indicate that the lower activity at the postreceptor step in women was due to differences in the capacity at the PKA or subsequent steps. In this way, it is worth noticing the strong correlation found in visceral fat between $\mathrm{Bt}_{2} \mathrm{cAMP}$ stimulated lipolysis and both HSL activity $(\mathrm{r}=0.537$, $\mathrm{p}=0.015)$ and fat cell size $(\mathrm{r}=0.499, \mathrm{p}=0.021)$, in accordance with that found by other authors [7, 28, 29]. In summary, the main gender-related differences are located in the visceral adipose tissue, with women exhibiting a higher sensitivity to catecholamines associated to an increased provision of $\beta$-ARs, while men showed an enhanced lipolytic capacity at the postreceptor level. In men, the increased fat cell size, the basal rate of lipolysis and the noradrenaline-induced glycerol release per cell would be in accordance with an attempt to limit cellular hypertrophy and would be of importance for the metabolic disorders associated to obesity.

\section{Acknowledgements}

The authors wish to express their gratitude to J.A. Soro, head of the General and Digestive Surgery Department and Service of Son Dureta University Hospital, as well as to the rest of the staff, for their excellent collaboration in providing us with adipose tissue specimens, and to B. Alonso for her assistance with serum samples and data collection. We are grateful to Dr. F.B. Kraemer for kindly providing antibodies for HSL. We especially thank all the subjects who volunteered to participate in this study. This work was supported by grants BFI2000-0988-C06 from Dirección General de Enseñanza Superior e Investigación Científica and PI042377 and PI042294 from Fondo de Investigación Sanitaria of the Government of Spain.

\section{References}

Lafontan $\mathrm{M}$ and Berlan M: Fat cell $>5$ adrenergic receptors and the control of white and brown fat cell function. J Lipid Res 1993;34:1057-91.

- Arner P: Genetic variance and lipolysis regulation: implications for obesity. Ann $>6$ Med 2001;33:542-6.

-3 Lafontan M, Barbe P, Galitzky J, Tavernier G, Langin D, Carpene C, Bousquet-Melou A and Berlan M: Adrenergic regulation of adipocyte metabolism. Hum Reprod 1997;12:6-20. $>7$

-4 Zimmermann R, Strauss JG, Haemmerle G, Schoiswohl G, Birner-Gruenberger R, Riederer M, Lass A, Neuberger G, Eisenhaber F, Hermetter A and Zechner $\mathrm{R}$ : Fat mobilization in adipose tissue is promoted by adipose triglyceride lipase. Science 2004;306:1383-6.
}

Raben DM and Baldassare JJ: A new lipase in regulating lipid mobilization: hormone-sensitive lipase is not alone. Trends Endocrinol Metab 2005;16:356.

Lake AC, Sun Y, Li JL, Kim JE, Johnson JW, Li D, Revett T, Shih HH, Liu W, Paulsen JE and Gimeno RE: Expression, 9 regulation, and triglyceride hydrolase activity of Adiponutrin family members. J Lipid Res 2005;46:2477-87.

Large V, Reynisdottir S, Langin D, Fredby K, Klannemark M, Holm C and Arner P: Decreased expression and function of adipocyte hormone-sensitive lipase in subcutaneous fat cells of obese subjects. J Lipid Res 1999;40:2059-66.
Van Harmelen V, Lonnqvist F, Thorne A, Wennlund A, Large V, Reynisdottir S and Arner P: Noradrenaline-induced lipolysis in isolated mesenteric, omental and subcutaneous adipocytes from obese subjects. Int J Obes Relat Metab Disord 1997;21:972-9.

van Harmelen V, Dicker A, Ryden M, Hauner H, Lonnqvist F, Naslund E and Arner P: Increased lipolysis and decreased leptin production by human omental as compared with subcutaneous preadipocytes. Diabetes 2002;51:202936.

Arner P: Differences in lipolysis between human subcutaneous and omental adipose tissues. Ann Med 1995;27:435-8. 
11 Hellmer J, Marcus C, Sonnenfeld T and Arner P: Mechanisms for differences in lipolysis between human subcutaneous and omental fat cells. J Clin Endocrinol Metab 1992;75:15-20.

$>12$ Hoffstedt J, Arner P, Hellers G and Lonnqvist F: Variation in adrenergic regulation of lipolysis between omental and subcutaneous adipocytes from obese and non-obese men. J Lipid Res 1997;38:795-804.

13 Bjorntorp P: Body fat distribution, insulin resistance, and metabolic diseases. Nutrition 1997;13:795-803.

$>14$ Kissebah AH and Krakower GR: Regional adiposity and morbidity. Physiol Rev 1994;74:761-811.

Williams CM: Lipid metabolism in women. Proc Nutr Soc 2004;63:153-60.

Llado I, Rodriguez-Cuenca S, Pujol E, Monjo M, Estrany ME, Roca $\mathrm{P}$ and Palou A: Gender effects on adrenergic receptor expression and lipolysis in white adipose tissue of rats. Obes Res 2002;10:296-305.

17 Llado I, Estrany ME, Rodriguez E, Amengual B, Roca P and Palou A: Effects of cafeteria diet feeding on beta3adrenoceptor expression and lipolytic activity in white adipose tissue of male and female rats. Int $\mathbf{J}$ Obes Relat Metab Disord 2000;24:1396-404.

18 Lonnqvist F, Thorne A, Large V and Arner P: Sex differences in visceral fat lipolysis and metabolic complications of obesity. Arterioscler Thromb Vasc Biol 1997; 17:1472-80.

$>19$ Kolehmainen M, Vidal H, Ohisalo JJ, Pirinen E, Alhava E and Uusitupa MI: Hormone sensitive lipase expression and adipose tissue metabolism show gender difference in obese subjects after weight loss. Int J Obes Relat Metab Disord 2002;26:6-16.
Kraemer FB, Patel S, Saedi MS and Sztalryd C: Detection of hormonesensitive lipase in various tissues. I. Expression of an HSL/bacterial fusion protein and generation of anti-HSL antibodies. J Lipid Res 1993;34:663-71. Scopinaro N, Adami GF, Marinari GM, Gianetta E, Traverso E, Friedman D, Camerini G, Baschieri G and Simonelli A: Biliopancreatic diversion. World J Surg 1998;22:936-46.

22 Robdell M: Metabolism of isolated fat cells. I. Effects of hormones on glucose metabolism and lipolysis. J Biol Chem 1964;239:375-80.

Pujol E, Rodriguez-Cuenca S, Frontera M, Justo R, Llado I, Kraemer FB, Gianotti $M$ and Roca P: Gender- and site-related effects on lipolytic capacity of rat white adipose tissue. Cell Mol Life Sci 2003;60:1982-9.

24 Bradford MM: A rapid and sensitive method for the quantitation of microgram quantities of protein utilizing the principle of protein-dye binding. Anal Biochem 1976;72:248-54.

25 Puigserver P, Llado I, Palou A and Gianotti $\mathrm{M}$ : Evidence for masking of brown adipose tissue mitochondrial GDPbinding sites in response to fasting in rats made obese by dietary manipulation. Effects of reversion to standard diet. Biochem J 1991;279:575-9.

Motulsky HJ and Ransnas LA: Fitting curves to data using nonlinear regression: a practical and nonmathematical review. Faseb J 1987;1:365-74.

27 Bullo M, Garcia-Lorda P, PeinadoOnsurbe J, Hernandez M, Del Castillo D, Argiles JM and Salas-Salvado J: TNFalpha expression of subcutaneous adipose tissue in obese and morbid obese females: relationship to adipocyte LPL activity and leptin synthesis. Int $\mathrm{J}$ Obes Relat Metab Disord 2002;26:652-8.
Lofgren P, Hoffstedt J, Ryden M, Thorne A, Holm C, Wahrenberg $\mathrm{H}$ and Arner P: Major gender differences in the lipolytic capacity of abdominal subcutaneous fat cells in obesity observed before and after long-term weight reduction. J Clin Endocrinol Metab 2002;87:764-71.

29 Reynisdottir S, Dauzats M, Thorne A and Langin D: Comparison of hormonesensitive lipase activity in visceral and subcutaneous human adipose tissue. J Clin Endocrinol Metab 1997;82:4162-6.

Yeaman SJ: Hormone-sensitive lipasenew roles for an old enzyme. Biochem $\mathbf{J}$ 2004;379:11-22.

Ray H, Beylot M, Arner P, Larrouy D, Langin D, Holm C and Large V: The presence of a catalytically inactive form of hormone-sensitive lipase is associated with decreased lipolysis in abdominal subcutaneous adipose tissue of obese subjects. Diabetes 2003;52:1417-22.

Kissebah AH, Vydelingum N, Murray R, Evans DJ, Hartz AJ, Kalkhoff RK and Adams PW: Relation of body fat distribution to metabolic complications of obesity. J Clin Endocrinol Metab 1982;54:254-60.

Jacobsson B and Smith U: Effect of cell size on lipolysis and antilipolytic action of insulin in human fat cells. J Lipid Res 1972;13:651-6.

34 Ramis JM, Bibiloni B, Moreiro J, GarciaSanz JM, Salinas R, Proenza AM and Llado I: Tissue leptin and plasma insulin are associated with lipoprotein lipase activity in severely obese patients. J Nutr Biochem 2005;16:279-85.

Arner P: Catecholamine-induced lipolysis in obesity. Int J Obes Relat Metab Disord 1999;23:10-3. 